\title{
Distribution of Health Care Expenditures for HIV-Infected Patients
}

\author{
Ray Y. Chen, ${ }^{1}$ Neil A. Accortt, ${ }^{4}$ Andrew 0. Westfall, ${ }^{2}$ Michael J. Mugavero, ${ }^{1}$ James L. Raper, ${ }^{1}$ Gretchen A. Cloud, ${ }^{4}$ \\ Beth K. Stone,, Jerome Carter, ${ }^{1}$ Stephanie Call,' Maria Pisu, ${ }^{3}$ Jeroan Allison, ${ }^{1}$ and Michael S. Saag' \\ Departments of ${ }^{1}$ Internal Medicine, ${ }^{2}$ Biostatistics, and ${ }^{3}$ Preventive Medicine and ${ }^{4}$ Medical Statistics Section, School of Medicine, \\ University of Alabama at Birmingham, Birmingham, Alabama
}

\section{(See the editorial commentary by Mayer and Chaguturu on pages 1011-3)}

Background. Health care expenditures for persons infected with human immunodeficiency virus (HIV) in the United State determined on the basis of actual health care use have not been reported in the era of highly active antiretroviral therapy.

Methods. Patients receiving primary care at the University of Alabama at Birmingham HIV clinic were included in the study. All encounters (except emergency room visits) that occurred within the University of Alabama at Birmingham Hospital System from 1 March 2000 to 1 March 2001 were analyzed. Medication expenditures were determined on the basis of 2001 average wholesale price. Hospitalization expenditures were determined on the basis of 2001 Medicare diagnostic related group reimbursement rates. Clinic expenditures were determined on the basis of 2001 Medicare current procedural terminology reimbursement rates.

Results. Among the 635 patients, total annual expenditures for patients with $\mathrm{CD}^{+}$cell counts $<50$ cells $/ \mu \mathrm{L}$ $\left(\$ 36,533\right.$ per patient) were 2.6-times greater than total annual expenditures for patients with $\mathrm{CD}^{+}$cell counts $\geqslant 350$ cells $/ \mu \mathrm{L}$ ( $\$ 13,885$ per patient), primarily because of increased expenditures for nonantiretroviral medication and hospitalization. Expenditures for highly active antiretroviral therapy were relatively constant at $\sim 10,500$ per patient per year across $\mathrm{CD} 4{ }^{+}$cell count strata. Outpatient expenditures were $\$ 1558$ per patient per year; however, the clinic and physician component of these expenditures represented only $\$ 359$ per patient per year, or $2 \%$ of annual expenses. Health care expenditures for patients with HIV infection increased substantially for those with more-advanced disease and were driven predominantly by medication costs (which accounted for $71 \%-84 \%$ of annual expenses).

Conclusions. Physician reimbursements, even with 100\% billing and collections, are inadequate to support the activities of most clinics providing HIV care. These findings have important implications for the continued support of HIV treatment programs in the United States.

The use of HAART has led to dramatic decreases in the morbidity and mortality of patients infected with HIV [1-3]. These benefits, however, come with the expense of HAART, estimated to be $\$ 10,000-\$ 15,000$ per patient per year in the United States [4]. A number of studies have estimated the monthly health care expenditures incurred by HIV-infected patients and have investigated the relationship between these expenditures and $\mathrm{CD}^{+}$cell counts [5-15]. Yet, there is no infor-

Received 21 May 2005; accepted 2 November 2005; electronically published 22 February 2006.

Reprints or correspondence: Dr. Michael S. Saag, UAB HIV Outpatient Clinic, CCB Rm. 142, 908 20th St. South, Birmingham, AL 35294-2050 (msaag@uab.edu).

Clinical Infectious Diseases 2006; 42:1003-10

(C) 2006 by the Infectious Diseases Society of America. All rights reserved. $1058-4838 / 2006 / 4207-0019 \$ 15.00$ mation determined on the basis of actual health care use, in quantitative terms, regarding actual expenditures in the contemporary HAART era. Moreover, no prior studies have been able to evaluate the annual expenditures for a patient whose $\mathrm{CD} 4^{+}$cell count increases or decreases during the course of therapy.

We investigated questions related to the relationship among the cost components of care and examined how a change in clinical status affected cost expenditures over a period of 1 year. Answers to these questions, determined in the context of the contemporary HAART era, are essential if policy makers and third-party payers are to make informed decisions about the optimal allocation of scarce resources. To address these questions, we performed an analysis of expenditures using the University of Alabama at Birmingham (UAB) Studies 
Table 1. Cost components and expenditures included in a study of patients with HIV infection at the University of Alabama at Birmingham.

\begin{tabular}{|c|c|c|}
\hline Cost component & Expenditures & Cost data \\
\hline Hospital costs & $\begin{array}{l}\text { Inpatient medications, radiological examinations, labora- } \\
\text { tory studies, and procedures, by Medicare reimburse- } \\
\text { ment rates for diagnostic related group codes }\end{array}$ & $\begin{array}{l}\text { Medicare diagnostic related group, based on hospital } \\
\text { diagnoses }\end{array}$ \\
\hline Antiretroviral medications & $\begin{array}{l}\text { Outpatient antiretroviral medications, by average whole- } \\
\text { sale price }\end{array}$ & Average wholesale price, using stop and start dates per drug \\
\hline Nonantiretroviral medications & $\begin{array}{l}\text { All nonantiretroviral outpatient medications, including an- } \\
\text { tibiotics, by average wholesale price }\end{array}$ & Average wholesale price, using stop and start dates per drug \\
\hline Physician/clinic fees & $\begin{array}{l}\text { Physician fees included inpatient and outpatient physi- } \\
\text { cian professional fees; clinic fees included medication } \\
\text { services (i.e., infusions, injections, and chemotherapy) } \\
\text { and charges for use of space }\end{array}$ & $\begin{array}{l}\text { Medicare reimbursements paid via current procedural } \\
\text { terminology codes for visit }\end{array}$ \\
\hline Other outpatient expenditures & $\begin{array}{l}\text { Outpatient procedures not performed in the HIV outpa- } \\
\text { tient clinic (i.e., laboratory studies, radiological exami- } \\
\text { nations, and outpatient surgeries), home health care, } \\
\text { and hospice care }\end{array}$ & $\begin{array}{l}\text { Medicare reimbursements paid via current procedural } \\
\text { terminology codes }\end{array}$ \\
\hline
\end{tabular}

of HIV/AIDS Longitudinal Outcome Metrics database. This database combines clinical data, laboratory data, and data on health care use for all of its patients to monitor and measure outcomes of care over time. Therefore, this database provides the opportunity to investigate the relationship between health care expenditures and $\mathrm{CD} 4^{+}$cell counts, to evaluate the contribution of each category of expenditures to overall expenditures, and to quantitate the effect of an increase or decrease in $\mathrm{CD}^{+}$cell count on expenditures.

\section{METHODS}

In January 1994, the UAB outpatient HIV clinic initiated an ongoing database (Studies of HIV/AIDS Longitudinal Outcome Metrics) that collected clinical information for all patients seen. Trained medical records personnel used standardized procedures to abstract clinical and treatment data from medical records daily. Laboratory data were downloaded from the hospital laboratory system directly into the database. All outside laboratory values were entered into the database manually (quality control assessments demonstrated an error rate of $<5 \%$ ). Health care use data were added to the database beginning in March 1999.

All patients included in this study received their primary care at the UAB HIV clinic, had a baseline $\mathrm{CD} 4^{+}$cell count on 1 March 2000 ( \pm 90 days), and had at least 1 follow-up clinic visit or hospitalization between 1 June 2000 and 1 March 2001. Patients who had a follow-up visit after 1 June 2000 but subsequently died before 1 March 2001 were also included.

Hospitalization, laboratory, procedure, and clinic use data were obtained from the UAB Health System between 1 March 2000 and 1 March 2001; data pertaining to emergency department visits that did not result in an inpatient admission were not included. Health care received outside of the UAB health system was not captured. An expenditure was defined as the cost outlay required to pay for any service or medication used by a patient during the time of observation. Information on use of clinical services was translated into expenditures through assignment of cost per unit activity on the basis of 2001 Medicare reimbursement rates [16]. Although nearly 30\% of our patients are uninsured and our usual collection rate is $40 \%$, for analysis purposes, we assumed that all patients had Medicare insurance, that there was complete billing for all health care use, and that the collection rate was 100\%. Expenditures were broken down by cost component, as shown in table 1 .

Hospitalization expenditures were determined on the basis of Medicare reimbursement rates for diagnostic related group codes for each admission [17]. The hospital-associated expenditures included all technical expenditures associated with the hospital stay, such as inpatient medications, radiological studies, procedures, and laboratory studies, but did not include physicians' professional fees incurred during the hospital stay; both inpatient and outpatient physician professional fees were included in clinic/physician expenditures.

Data on the use of outpatient clinical services was obtained by a data warehouse query of services rendered using the IDX database system. This system captures all UAB service activity related to outpatient professional and technical fees, as well as use of all outpatient clinics, across the University Health System (including all subspecialty consultation and mental health visits), except for fees associated with emergency department visits that do not result in a hospitalization. Outpatient clinic use, which included level of clinic visits, delivery of outpatient medication services (such as delivery of infusions, injections, and chemotherapy), and laboratory use, was converted into expenditures on the basis of 2001 Medicare reimbursement rates 
using current procedural terminology codes [18]. Substance abuse treatment is provided through a federally funded grant and was not captured in our outpatient clinic visits. Sensitivity analyses were conducted to assess the potential impact of the inclusion of substance abuse treatment, missed emergency room visits, and missed visits at other facilities on outcomes.

Medication expenditures were based on use data as recorded in the outpatient medical record. At each patient visit, the clinic health care provider recorded all changes to the patient medication list, including date of initiation of new medications, date of discontinuation of previous medications, and dosages. The changes included all medications prescribed by that provider or by any other provider as reported by the patient. Medication, dosage, and start and stop dates were entered into the clinical database within $24 \mathrm{~h}$ after each patient visit. Outpatient medication infusion and injection expenditures were included in the physician/clinic expenditures, not in the medication expenditures. Medication expenditures were assigned on the basis of the 2001 average wholesale price (AWP) for each medication recorded in the clinic database, incorporating duration of therapy as calculated through medication start and stop dates [19]. Although it was recognized that most medication payment programs often received substantial discounts, the high degree of variability in discounts between programs (and even within drug classes) made it impossible to use a consistent, meaningful discounted price. AWP was chosen as the standard for this study, because it forms the primary basis on which discounted pricing is determined. A sensitivity analysis was conducted to assess the impact of the decision to use AWP on the reported findings.

Expenditure data were aggregated into two 6-month intervals. Patients were categorized by baseline $\mathrm{CD} 4^{+}$cell count into 4 strata: $<50$ cells $/ \mu \mathrm{L}, 50-199$ cells $/ \mu \mathrm{L}, 200-349$ cells $/ \mu \mathrm{L}$, and $\geqslant 350$ cells $/ \mu \mathrm{L}$. Improvement status was defined by whether a patient's $\mathrm{CD}^{+}$cell count category at 6 months had changed relative to the baseline category. Patients were considered to have experienced improvement if their 6-month $\mathrm{CD}^{+}$cell count moved them into a higher $\mathrm{CD} 4^{+}$cell count stratum, and their condition was considered to have worsened if they moved to a lower $\mathrm{CD}^{+}$cell count stratum. Patients whose $\mathrm{CD} 4^{+}$stratum did not change were considered to be the same, including those patients whose $\mathrm{CD} 4^{+}$cell counts remained in the highest or lowest $\mathrm{CD}^{+}$cell count group. Patients were then stratified by $\mathrm{CD}^{+}$improvement status, and annualized expenditures were determined for each group. Annual costs represented the sum incurred during both 6-month intervals.

To correct for the nonnormal distribution of the annual cost data, we transformed the data by taking the natural log of the annual costs. All analyses were conducted using these transformed data, but results are presented using the actual costs. Analysis of variance was used to assess for overall significance of differences in expenditures between $\mathrm{CD}^{+}$cell count categories, and Duncan's multiple range test was used to control for the analysis of variance pair-wise comparisons at the .05 level. Statistical analyses were performed using SAS software, version 8.2 (SAS Institute).

\section{RESULTS}

Of the 1041 patients seen between 1 March 2000 ( \pm 90 days) and 1 March 2001, 635 met the inclusion criteria; 309 patients did not have a baseline $\mathrm{CD} 4^{+}$cell count within the specified time window, and 97 patients did not have a follow-up visit or hospitalization. The baseline demographic characteristics of this cohort are listed in table 2. These patients were predominantly white men who had sex with men, and most of the patients had good virologic responses to HAART (median viral load, $2.4 \log _{10}$ copies $/ \mathrm{mL}$ ). More than $50 \%$ of the patients had

Table 2. Baseline characteristics of the 635 patients from the University of Alabama at Birmingham HIV outpatient clinic included in the study cohort.

\begin{tabular}{|c|c|}
\hline Characteristic & $\begin{array}{l}\text { Patients } \\
(n=635)\end{array}$ \\
\hline \multicolumn{2}{|l|}{ Demographic characteristic } \\
\hline Age, median years (range) & $35(18-66)$ \\
\hline Male sex & 491 (77.3) \\
\hline White race & $376(59.2)$ \\
\hline \multicolumn{2}{|l|}{ Behavioral characteristic } \\
\hline Men who have sex with men & $394(62.0)$ \\
\hline Injection drug use & $65(10.2)$ \\
\hline \multicolumn{2}{|l|}{ Clinical characteristic } \\
\hline $\begin{array}{r}\mathrm{CD} 4^{+} \text {cell count at baseline, } \\
\text { median cells } / \mu \mathrm{L} \text { (range) }\end{array}$ & $367(2-2671)$ \\
\hline \multicolumn{2}{|l|}{$\mathrm{CD}^{+}$cell count strata } \\
\hline$<50$ cells $/ \mathrm{mL}$ & $62(9.8)$ \\
\hline 50-199 cells $/ \mu \mathrm{L}$ & $99(15.6)$ \\
\hline 200-249 cells $/ \mu \mathrm{L}$ & $143(22.5)$ \\
\hline$\geqslant 350 \mathrm{cells} / \mu \mathrm{L}$ & $331(52.1)$ \\
\hline $\begin{array}{l}\mathrm{CD}^{+}{ }^{+} \text {cell count pre-HAART, } \\
\text { median nadir cells } / \mu \mathrm{L}^{\mathrm{a}}\end{array}$ & 144 \\
\hline $\begin{array}{l}\text { Viral load at baseline, } \\
\text { median } \log _{10} \text { copies } / \mathrm{mL} \text { (range) }\end{array}$ & $2.4(<1.3-6.0)$ \\
\hline Receiving HAART ${ }^{\mathrm{b}}$ & $510(80.3)$ \\
\hline History of opportunistic infection & $171(26.9)$ \\
\hline Hyperlipidemia & $325(51.2)$ \\
\hline Diabetes mellitus & $65(10.2)$ \\
\hline Coronary artery disease & $6(1.0)$ \\
\hline \multicolumn{2}{|l|}{ Insurance status } \\
\hline Public & $197(31.0)$ \\
\hline Private & $344(54.2)$ \\
\hline None & $94(14.8)$ \\
\hline
\end{tabular}


$\mathrm{CD}^{+}$cell counts $\geqslant 350$ cells $/ \mu \mathrm{L}$. Twenty patients died during the analysis period; the median duration of follow-up for these patients was 7 months.

The annual expenditure data were aggregated into two 6month intervals, with the mean 1-year totals for each $\mathrm{CD} 4^{+}$ cell count category listed in table 3 . The distribution of the total expenditures differed significantly across $\mathrm{CD} 4^{+}$cell count categories; patients with $\mathrm{CD} 4^{+}$cell counts $<50$ cells/ $\mu \mathrm{L}$ generated $\$ 36,532$ per patient per year in expenditures, whereas patients with $\mathrm{CD}^{+}$cell counts $\geqslant 350$ cells $/ \mu \mathrm{L}$ generated expenditures of $\$ 13,885$ per patient per year $(P<.0001)$. In contrast, viral load strata were less discriminatory, with strata of $<50$ copies/mL, 50-4999 copies/mL, 5000-99,999 copies/mL, and $>100,000$ copies/mL resulting in expenditures of $\$ 17,142$, $\$ 17,176, \$ 18,295$, and $\$ 28,825$ per patient per year, respectively.

The increased expenditures for patients with low $\mathrm{CD} 4^{+}$cell counts were predominantly attributable to increased nonantiretroviral medication and hospitalization expenditures (table 3; figure $1 A$ and $1 B$ ), although all expenditures were significantly higher for patients with $\mathrm{CD}^{+}$cell counts $<50$ cells $/ \mu \mathrm{L}$ than they were for patients with $\mathrm{CD}^{+}$cell counts $\geqslant 350$ cells $/ \mu \mathrm{L}$ $(P \leqslant .0006)$. Compared with patients with $\mathrm{CD} 4^{+}$cell counts $\geqslant 350$ cells $/ \mu \mathrm{L}$, patients with $\mathrm{CD} 4^{+}$cell counts $<50$ cells $/ \mu \mathrm{L}$ had hospitalization expenditures that were almost 6 -fold greater and nonantiretroviral medication expenditures that were almost 8fold greater. Fifty-one percent of nonantiretroviral medication costs for patients with $\mathrm{CD}^{+}$cell counts of $<50$ cells $/ \mu \mathrm{L}$ were due to antimicrobials, compared with only $17 \%$ for patients with $\mathrm{CD}^{+}$cell counts $\geqslant 350$ cells $/ \mu \mathrm{L}$. These expenditures were distributed evenly over the population of patients with $\mathrm{CD} 4^{+}$ cell counts $<50$ cells $/ \mu \mathrm{L}$ and were not unduly influenced by outliers. Because antiretroviral medication costs remained relatively constant across CD4 ${ }^{+}$cell count strata (\$9407-\$11,935 per patient per year), the proportion of overall expenditures attributable to use of antiretroviral therapy more than doubled for patients with $\mathrm{CD} 4^{+}$cell counts $\geqslant 350$ cells $/ \mu \mathrm{L}(68 \%)$, compared with patients with $\mathrm{CD} 4^{+}$cell counts $<50$ cells $/ \mu \mathrm{L}(30 \%)$. Two percent or less of all expenditures was due to physician/ clinic fees, with an average annual expenditure of $<\$ 400$ per patient per year. This figure assumed that all patients had Medicare health insurance and that the collection rate per physician/ clinic encounter was $100 \%$.

To assess the impact of a decrease in immunologic status during the study period, expenditures were stratified by the change in each patient's $\mathrm{CD} 4^{+}$cell count status between baseline and 6 months later (figure $1 B$ ). A decrease in $\mathrm{CD}^{+}$cell count category was always associated with increased expenditures, but this increase was statistically significant only for patients whose baseline $\mathrm{CD}^{+}$cell count was in the $50-199$ cells $/ \mu \mathrm{L}$ category $(P=.003)$. The differences in expenditures for these patients are shown in figure $1 B$, in which patients with a baseline $\mathrm{CD} 4^{+}$ cell count between $50-199$ cells/ $\mu \mathrm{L}$ were stratified by cost component and improvement status. In a manner similar to that seen with total expenditures, the increased expenditures associated with a decline in $\mathrm{CD} 4^{+}$cell count were predominantly attributable to nonantiretroviral medications $(P=.03)$ and hospitalizations $(P=.05)$. Expenditures for other cost components were not significantly different.

We conducted a similar analysis of data from 1 March 1999 through 1 March 2000 (data not shown) and found very similar results for the mean annual expenditures, $\mathrm{CD} 4^{+}$cell count expenditure distribution, and contribution of expenditure category to overall expenditures. Because the data from 2000-2001 were more recent, we elected to present only those results. However, this does show that our results were consistent over a 2-year period.

Sensitivity analyses demonstrated little impact on the overall findings when adjustments were made for missing data regarding emergency room visits, substance abuse/mental health visits, visits at other health care facilities, or the use of full AWP in our study (table 4 ). Approximately $25 \%$ of our patients have substance abuse/mental health problems that warrant outpatient visits for therapy. If liberal adjustments are made in our outpatient use data to adjust for the missing data regarding emergency room visits, visits to other facilities, and substance abuse/mental health visits such that the total outpatient costs

Table 3. Mean annual expenditure per patient by cost component and CD4+ cell count category for 635 patients from the University of Alabama at Birmingham HIV outpatient clinic.

\begin{tabular}{|c|c|c|c|c|c|c|c|}
\hline \multirow[b]{2}{*}{$\mathrm{CD}^{+}$cell count category } & \multirow[b]{2}{*}{$\begin{array}{c}\text { No. of } \\
\text { patients }\end{array}$} & \multicolumn{6}{|c|}{ Cost per patient per year ( $\%$ of total cost), by cost category } \\
\hline & & Total cost & $\begin{array}{l}\text { Antiretroviral } \\
\text { medication }\end{array}$ & $\begin{array}{c}\text { Nonantiretroviral } \\
\text { medication }\end{array}$ & $\begin{array}{l}\text { Hospital } \\
\text { costs }\end{array}$ & $\begin{array}{c}\text { Other } \\
\text { outpatient } \\
\text { costs }^{\text {a }}\end{array}$ & $\begin{array}{c}\text { Physician/clinic } \\
\text { costs }\end{array}$ \\
\hline$<50$ cells $/ \mu \mathrm{L}$ & 62 & $\$ 36,532(100)$ & $\$ 10,855(30)$ & $\$ 14,882(41)$ & $\$ 8353(23)$ & $\$ 1909(5)$ & $\$ 533(1)$ \\
\hline 50-199 cells/ $\mu \mathrm{L}$ & 99 & $\$ 23,864(100)$ & $\$ 11,862(50)$ & $\$ 6685(28)$ & $\$ 3369(14)$ & $\$ 1416(6)$ & $\$ 532(2)$ \\
\hline 200-349 cells/ $\mu \mathrm{L}$ & 143 & $\$ 18,274(100)$ & $\$ 11,935(65)$ & $\$ 3452$ (19) & $\$ 1186(7)$ & $\$ 1365(7)$ & $\$ 336(2)$ \\
\hline$\geqslant 350$ cells $/ \mu \mathrm{L}$ & 331 & $\$ 13,885(100)$ & $\$ 9407$ (68) & $\$ 1855$ (13) & $\$ 1408(10)$ & $\$ 930(7)$ & $\$ 285(2)$ \\
\hline All & 635 & $\$ 18,640(100)$ & $\$ 10,500(56)$ & $\$ 4240(23)$ & $\$ 2342$ (13) & $\$ 1199(6)$ & $\$ 359(2)$ \\
\hline
\end{tabular}

a Other outpatient costs include outpatient radiological examinations, laboratory tests, procedures, and home health care. 
A

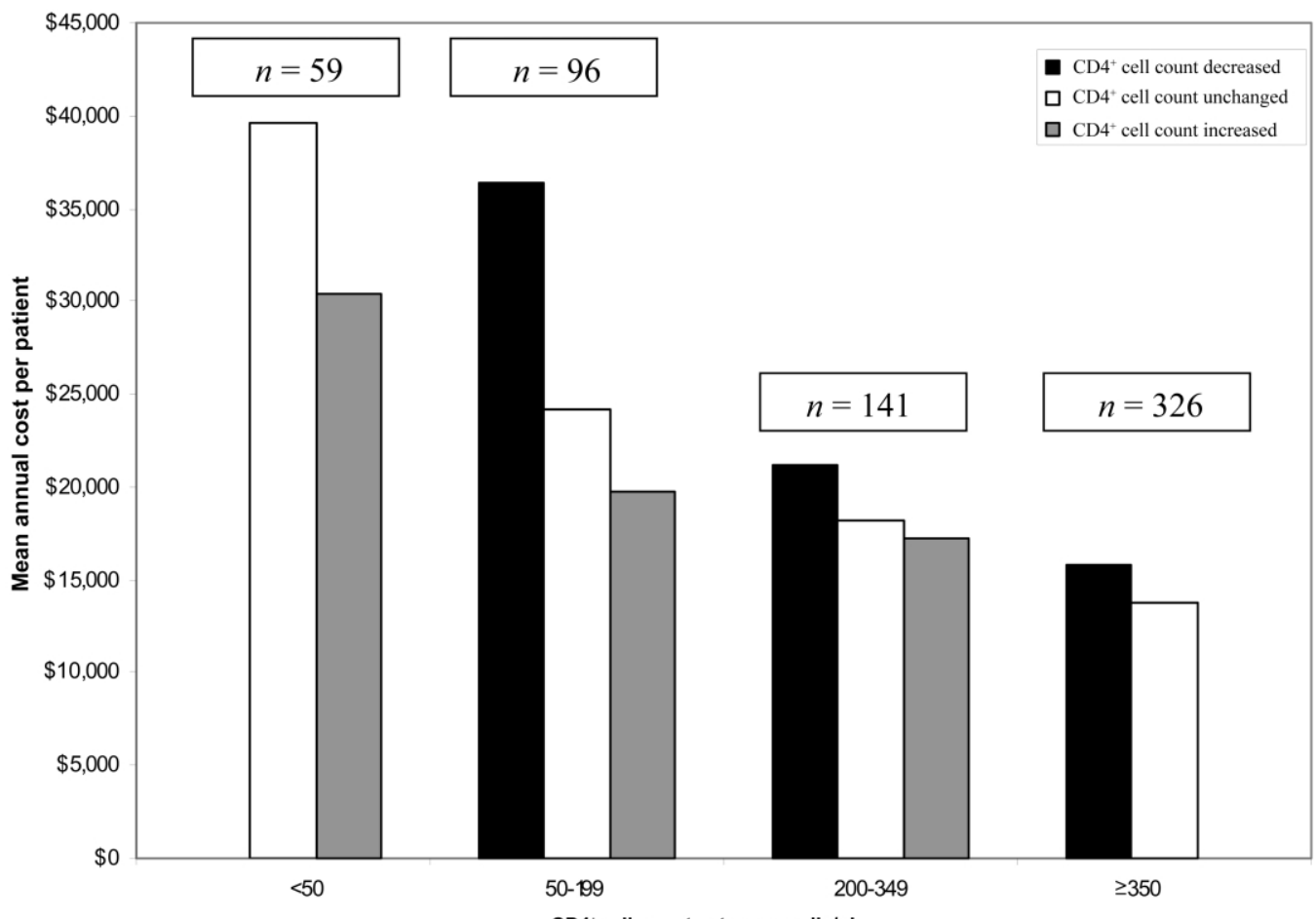

B

$\mathrm{CD}^{+}$cell count category, cells/ $\mathrm{L}$

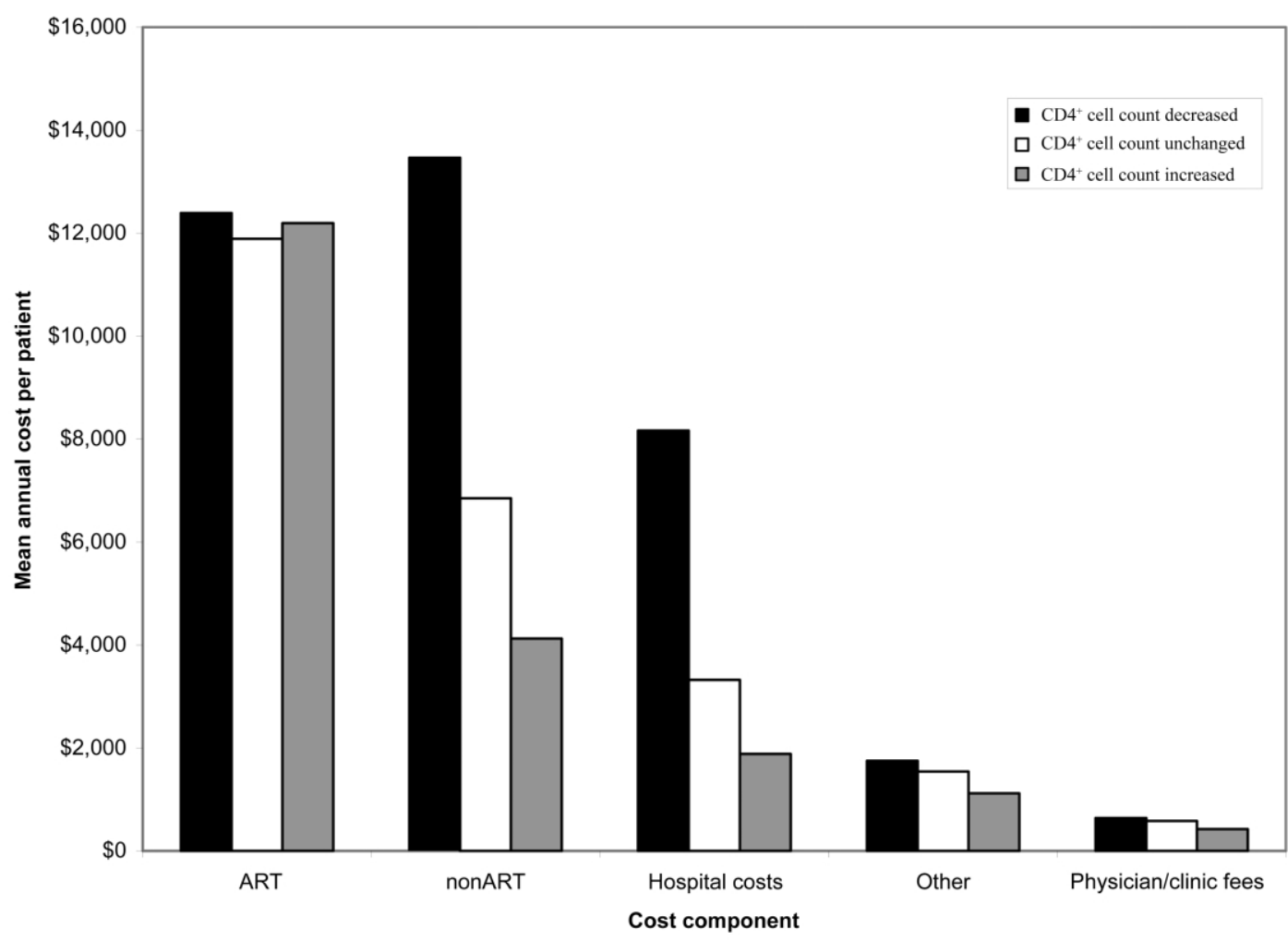

Figure 1. A, Assessment of changes in annual expenditures for patients whose CD4 ${ }^{+}$cell count status increased $(n=386)$, decreased $(n=102)$, or remained unchanged $(n=134)$ between baseline (1 March 2000) and 6 months (1 September 2000). A decrease in CD4 ${ }^{+}$cell count category was associated with a significant increase $(P=.003)$ in annual cost among patients initially assigned to the group of patients with $\mathrm{CD} 4^{+}$cell counts of 50-199 cells $/ \mu \mathrm{L}$. The cost differences in other CD4+ cell count categories were not significantly different $(P>.2)$. $B$, Assessment of the source of expenditures for patients initially assigned to the CD4 $4^{+}$cell count 50-199 cells/ $\mu \mathrm{L}$ group whose $\mathrm{CD} 4^{+}$cell count category increased, decreased, or stayed the same between baseline and 6 months. Nonantiretroviral medication $(P=.03)$ and hospital costs $(P=.05)$ for patients with a decrease in $\mathrm{CD}^{+}$cell count category were significantly increased, compared with costs for patients with an increase in CD4 ${ }^{+}$cell count category. Differences for other cost components were not significantly significant. ART, antiretroviral therapy. 
Table 4. Sensitivity analyses performed to assess impact of lower medication average wholesale pricing (AWP) and accounting for the costs of emergency room (ER) visits, substance abuse/mental health care costs, and the costs of unaccounted visits at other facilities.

\begin{tabular}{|c|c|c|c|c|}
\hline \multirow[b]{2}{*}{ Analysis } & \multicolumn{4}{|c|}{ Cost per patient per year ( $\%$ of total cost), by cost component } \\
\hline & $\begin{array}{l}\text { Medication } \\
\text { costs }\end{array}$ & $\begin{array}{l}\text { Hospital } \\
\text { costs }\end{array}$ & $\begin{array}{l}\text { Outpatient/other } \\
\text { costs }\end{array}$ & $\begin{array}{l}\text { Total } \\
\text { costs }\end{array}$ \\
\hline Initial & $\$ 14,740(79.1)$ & $\$ 2342(12.6)$ & $\$ 1558$ (8.4) & $\$ 18,640(100)$ \\
\hline Incorporating AWP discounted $25 \%$ & $\$ 11,055(73.9)$ & $\$ 2342(15.7)$ & $\$ 1558(10.4)$ & $\$ 14,955(100)$ \\
\hline Incorporating ER visits ${ }^{a}$ & $\$ 14,740(75.9)$ & $\$ 2342(12.1)$ & $\$ 2337(12.0)$ & $\$ 19,419(100)$ \\
\hline $\begin{array}{l}\text { Incorporating ER visits, substance abuse /mental } \\
\text { health care costs, and unaccounted visits }{ }^{b}\end{array}$ & $\$ 14,740(73.0)$ & $\$ 2342(11.6)$ & $\$ 3116(15.4)$ & $\$ 20,198(100)$ \\
\hline $\begin{array}{l}\text { Incorporating AWP discounted } 25 \%, \text { ER visits, } \\
\text { and substance abuse/mental health care costs }\end{array}$ & $\$ 11,055(70.3)$ & $\$ 2342(14.9)$ & $\$ 2337(14.9)$ & $\$ 15,734(100)$ \\
\hline $\begin{array}{l}\text { Combination of AWP discounted } 25 \% \text {, ER visits, } \\
\text { substance abuse/mental health care costs, and } \\
\text { unaccounted visits }{ }^{\text {b }}\end{array}$ & $\$ 11,055(66.9)$ & $\$ 2342(14.2)$ & $\$ 3116$ (18.9) & $\$ 16,513(100)$ \\
\hline
\end{tabular}

were doubled (from $\sim \$ 1300$ to $\sim \$ 2600$ per patient per year), the impact on our overall findings would be minimal. Medication costs would account for 73\% (compared with 79\%) of total costs, and HIV provider reimbursement would not increase, because these services are provided elsewhere. To explore the impact of discounted AWP pricing on our study findings, we reanalyzed our findings using a discount of $25 \%$ below AWP, a common discount for federal programs, such as the AIDS Drug Assistance Program (ADAP). With this adjustment, overall annual medication costs decreased from $\$ 14,740$ to $\$ 11,055$ per patient. Similarly, the overall expenditures decreased from $\$ 18,640$ to $\$ 14,955$ per patient per year. However, even in this scenario, medications still comprised $74 \%$ of overall expenditures, compared with $79 \%$ as determined in our primary analysis using full AWP. Using both a discount of 25\% below AWP and a doubling of outpatient expenditures to account for missing visits, medications still comprise $67 \%$ of total health care expenditures.

\section{DISCUSSION}

In this study, we determined per patient expenditures of care by directly measuring health system and medication use in a population of patients receiving primary HIV care at an academic medical center clinic in the southeastern United States. Our findings demonstrate a dramatic association between annual per patient expenditures and $\mathrm{CD} 4^{+}$cell counts, with patients in the lowest $\mathrm{CD} 4^{+}$category expending 2.6 times more health care dollars per year than patients in the highest CD $4^{+}$ cell count category. The single most expensive cost component was medications, accounting for $71 \%-84 \%$ of the overall health care costs, depending on stage of disease. Antiretroviral therapy represented $56 \%$ of the overall costs; however, the improvement in clinical status associated with successful antiretroviral therapy, as demonstrated by increases in $\mathrm{CD}^{+}$cell count, led to a reduction in health care expenditures in other areas. In particular, the sickest patients $\left(\mathrm{CD} 4^{+}\right.$cell count, $<50$ cells $\left./ \mu \mathrm{L}\right)$ require 8 -fold more nonantiretroviral medication expenditures and 6-fold more hospitalization expenditures than do the healthiest patients $\left(\mathrm{CD} 4^{+}\right.$cell count, $\geqslant 350$ cells $\left./ \mu \mathrm{L}\right)$. The most striking finding in this study, however, was the low expenditures for health care services provided by HIV physicians and clinics. Taken together, these findings demonstrate the relative cost of care in a fashion that informs policy makers, payers, and health care administrators.

To quantitate the reduction in expenditures associated with an increase in $\mathrm{CD}^{+}$cell count, we assessed the impact of changes in $\mathrm{CD}^{+}$cell count strata on annual expenditures during the year-long period of observation. Compared with patients who remained in the same $\mathrm{CD} 4^{+}$cell count stratum, patients who moved to a higher stratum during the year had lower annual expenditures, whereas patients who moved to a lower stratum experienced higher expenditures. Because antiretroviral drug effects principally drive improvements in $\mathrm{CD} 4^{+}$ cell counts, these findings further demonstrate the clinical and economic benefit of antiretroviral therapy among patients for whom therapy is currently recommended [20, 21]. Because these data do not account for indirect costs, such as lost wages for patients and caregivers, we speculate that the true economic benefit of increased $\mathrm{CD}^{+}$cell count status would likely be substantially greater. These data strongly validate the activity of federal programs, such as ADAP, in providing antiretroviral medications to patients who do not have prescription drug 
insurance coverage. Yet, ADAP programs in many states continue to experience budget shortfalls, and many patients are in jeopardy of not having access to needed medications [22, 23].

Despite the value of antiretroviral medications in increasing $\mathrm{CD}^{+}$cell counts and thereby decreasing costs, our data also highlight the large discrepancy between expenditures for medications and expenditures for other health care services. Most striking was the paucity of expenditures for clinic and physician services, representing $\leqslant 2 \%$ of all expenditures regardless of $\mathrm{CD}^{+}$cell count (range, $\$ 285-\$ 533$ per patient per year). This amount includes physician fees for inpatient as well as outpatient services, making the finding even more striking. As patient outcomes have improved, owing in large part to the proper use of antiretroviral therapy, the number of inpatients has declined, and the contribution of inpatient physician reimbursement is only a fraction of physician reimbursement. Indeed, the inpatient physician component was mostly concentrated among patients with $\mathrm{CD}^{+}$cell count $<50$ cell $/ \mathrm{mL}$ and contributed little to the overall expenditures.

We utilized AWP to assign costs to medications. Because $\mathrm{ADAP}$ and most third-party payers receive substantial discounts below AWP to purchase medications, our findings likely overestimate the actual contribution of medication expenditures to overall costs. We chose AWP for the final analysis because of the high degree of variability in the AWP discount, which varies widely from state to state and program to program. However, even when such discounts are factored in, our conclusions do not change. For example, in our sensitivity analysis, discounting the AWP by $25 \%$ (a common discount for federal programs such as ADAP) reduced overall expenditures, but medications still comprised $74 \%$ of overall costs. The sensitivity analyses addressed several other limitations of our study, including the absence of data on emergency room visits, potential missed visits outside of the UAB health system, and substance abuse treatment visits. Indeed, when adjustments are made for these missing data elements, the overall findings of our study do not change substantially, indicating that our results are robust.

Finally, the findings in our study were derived from actual health care use activities and medication records at our clinic and hospital. The relative proportion of medication expenditures and total overall expenditures is remarkably similar to that found in previous studies conducted in the HAART era, which used estimates of health care use or models of expenditures, suggesting that our findings are likely to be generalizable $[6,8,10,13,14]$.

In summary, the care of patients with HIV infection in the United States is associated with substantial expenditures that are driven predominantly by medication costs and are directly related to stage of disease, as determined by $\mathrm{CD} 4^{+}$cell count status. Owing to the impact of treatment on improving disease status, these expenditures are, paradoxically, both decreased by and driven by the use of antiretroviral medications. The degree of expenditures generated by clinic and physician fees is quite meager and is inadequate to cover the cost of care provision at most HIV clinics in the United States, the majority of which are subsidized by federal and state dollars. The direct measurement of annual expenditures associated with delivery of HIV care has important implications for the continued support of these HIV programs and for the development of future health care policy in the United States.

\section{Acknowledgments}

We acknowledge Dr. Catarina Kiefe and Dr. Norman Weissman for their thoughtful reviews of this manuscript.

Financial support. National Institutes of Health Centers for AIDS Research (P30-AI27767), National Institutes of Health General Clinical Record Center (M01-RR-00032), the University of Alabama at Birmingham Mary Fisher Clinical AIDS Research and Education Fund, and GlaxoSmithKline.

Potential conflicts of interest. M.S.S. has received research support from Gilead Sciences, GlaxoSmithKline, Panacos, Pfizer/Agouron, Roche Laboratories, Serono, and Tibotec, is a consultant for Boehringer-Ingelheim, Bristol-Myers Squibb, Gilead Sciences, GlaxoSmithKline, Panacos, Pfizer/Agouron, Roche Laboratories, Tanox, Tibotec/Virco, Trimeris, Vertex, and Mongram Biosciences. All other authors: no conflicts.

\section{References}

1. Palella FJ Jr, Delaney KM, Moorman AC, et al. Declining morbidity and mortality among patients with advanced human immunodeficiency virus infection. HIV Outpatient Study Investigators. N Engl J Med 1998; 338:853-60.

2. Moore RD, Chaisson RE. Natural history of HIV infection in the era of combination antiretroviral therapy. AIDS 1999; 13:1933-42.

3. Torres RA, Barr M. Impact of combination therapy for HIV infection on inpatient census. N Engl J Med 1997;336:1531-2.

4. Steinbrook R. Providing antiretroviral therapy for HIV infection. N Engl J Med 2001; 344:844-6.

5. Moore RD, Chaisson RE. Costs to Medicaid of advancing immunosuppression in an urban HIV-infected patient population in Maryland. J Acquir Immune Defic Syndr Hum Retrovirol 1997; 14:223-31.

6. Gebo KA, Chaisson RE, Folkemer JG, Bartlett JG, Moore RD. Costs of HIV medical care in the era of highly active antiretroviral therapy. AIDS 1999; 13:963-9.

7. Mole L, Ockrim K, Holodniy M. Decreased medical expenditures for care of HIV-seropositive patients: the impact of highly active antiretroviral therapy at a US Veterans Affairs Medical Center. Pharmacoeconomics 1999; 16:307-15.

8. Hellinger FJ, Fleishman JA. Estimating the national cost of treating people with HIV disease: patient, payer, and provider data. J Acquir Immune Defic Syndr 2000; 24:182-8.

9. Moore RD. Cost effectiveness of combination HIV therapy: 3 years later. Pharmacoeconomics 2000; 17:325-30.

10. Bozzette SA, Joyce G, McCaffrey DF, et al. Expenditures for the care of HIV-infected patients in the era of highly active antiretroviral therapy. N Engl J Med 2001;344:817-23.

11. Schackman BR, Goldie SJ, Weinstein MC, Losina E, Zhang H, Freedberg KA. Cost-effectiveness of earlier initiation of antiretroviral therapy for uninsured HIV-infected adults. Am J Public Health 2001;91: 1456-63.

12. Freedberg KA, Losina E, Weinstein MC, et al. The cost effectiveness of combination antiretroviral therapy for HIV disease. N Engl J Med 2001; 344:824-31.

13. Keiser P, Nassar N, Kvanli MB, Turner D, Smith JW, Skiest D. Long- 
term impact of highly active antiretroviral therapy on HIV-related health care costs. J Acquir Immune Defic Syndr 2001;27:14-9.

14. Hospital and outpatient health services utilization among HIV-infected patients in care in 1999. J Acquir Immune Defic Syndr 2002;30:21-6.

15. Schackman BR, Freedberg KA, Weinstein MC, et al. Cost-effectiveness implications of the timing of antiretroviral therapy in HIV-infected adults. Arch Intern Med 2002; 162:2478-86.

16. Medicare physician fee schedule look-up. Available at: http:// www.cms.hhs.gov/apps/pfslookup/. Accessed 3 February 2006.

17. CMS files for download for Medicare payment systems (formerly PUF files): 2001-payment rates-institutional providers [electronic data file]. Baltimore, MD: Centers for Medicare and Medicaid Services, 2001.

18. CMS files for download for Medicare payment systems (formerly PUF files): 2001-payment rates—noninstitutional providers [electronic data file]. Baltimore, MD: Centers for Medicare and Medicaid Services, 2001.
19. Cohen HE, ed. Drug topics red book. Montvale, NJ: Thomson Medical Economics, 2001.

20. Yeni PG, Hammer SM, Carpenter CC, et al. Antiretroviral treatment for adult HIV infection in 2002: updated recommendations of the International AIDS Society-USA Panel. JAMA 2002; 288:222-35.

21. Fauci AS, Bartlett JG, Goosby EP, Kates J. Guidelines for the use of antiretroviral agents in HIV-infected adults and adolescents. 4 February 2002. Available at: http://www.aidsinfo.nih.gov/. Accessed 3 February 2006.

22. Waiting for AIDS medications in the United States: an analysis of ADAP waiting lists. Henry J. Kaiser Family Foundation. Availabe at: http:// www.kff.org/hivaids/hiv 1211504pkg.cfm. Accessed 3 February 2006.

23. National Alliance of State and Territorial AIDS Directors: the ADAP watch. 10 August 2005. Available at: http://www.nastad.org/documents/ public/policy/publicpolicy/NASTAD_ADAP_Watch_Aug_05-FINAL .pdf. Accessed 3 February 2006. 